\title{
Risk Factors for Tuberculosis among Human Immunodeficiency Virus-infected Persons. A Case-control Study in Belo Horizonte, Minas Gerais, Brazil (1985-1996)
}

\author{
Antonio Carlos de Castro Toledo Jr. ${ }^{+}$, Dirceu Bartolomeu Greco, \\ Carlos Maurício Figueiredo Antunes
}

Serviço de Doenças Infecciosas e Parasitárias, Faculdade de Medicina, Universidade Federal de Minas Gerais, Av. Alfredo Balena 190 - $3^{\circ}$ andar, 30130-100 Belo Horizonte, MG, Brasil

The objective of this study was to identify tuberculosis risk factors and possible surrogate markers among human immunodeficiency virus (HIV)-infected persons. A retrospective case-control study was carried out at the HIV outpatient clinic of the Universidade Federal de Minas Gerais in Belo Horizonte. We reviewed the demographic, social-economical and medical data of 477 HIV-infected individuals evaluated from 1985 to 1996. The variables were submitted to an univariate and stratified analysis. Aids related complex (ARC), past history of pneumonia, past history of hospitalization, CD4 count and no antiretroviral use were identified as possible effect modifiers and confounding variables, and were submitted to logistic regression analysis by the stepwise method. ARC had an odds ratio (OR) of 3.5 (CI 95\% - 1.2-10.8) for tuberculosis development. Past history of pneumonia (OR 1.7 - CI 95\% 0.6-5.2) and the CD4 count (OR 0.4 - CI 0.2-1.2) had no statistical significance. These results show that ARC is an important clinical surrogate for tuberculosis in HIV-infected patients. Despite the need of confirmation in future studies, these results suggest that the ideal moment for tuberculosis chemoprophylaxis could be previous to the introduction of antiretroviral treatment or even just after the diagnosis of HIV infection.

Key words: tuberculosis - human immunodeficiency virus/Aids - risk factors - PPD skin test - CD4 antiretroviral therapy - chemoprophylaxis - Minas Gerais - Brazil

Tuberculosis was not given its true importance for many years, but is still a major public health problem. Despite the case reduction occurred in the beginning of the century, the disease was stable at a high endemic level in many developing countries (Styblo 1989). This stability shows lack symptomatic cases control, maybe related to delay in diagnosis and to low cure rate (Rieder et al. 1989, Styblo 1989, Kantor et al. 1994).

The human immunodeficiency virus (HIV)/Aids epidemic facilitated the resurgence of tuberculosis, due to the importance of these diseases interaction. The impact of HIV/Aids on tuberculosis was first seen in the 80's. In the United States, the reversion of the tuberculosis incidence-lowering trend was observed. Between 1985 and 1992, there was an

This study was sponsored by CN/DST/Aids, Brazilian Ministry of Health.

${ }^{+}$Corresponding author. Fax: +55-31-335.7988. E-mail: toledoac@ig.com.br

Received 6 July 1999

Accepted 22 March 2000 excess of 51,700 new cases (Cantwell et al. 1994), and Mycobacterium tuberculosis-HIV interaction was considered the main cause (Ellner et al. 1993). In 1988, similar trend change was observed in England and Wales (Citron 1988). In sub-Saharan Africa there is an important overlap of the two diseases, where in some countries the number of tuberculosis new cases had doubled in the last years (Arachi 1991).

The tuberculosis endemic in Brazil has a moderate incidence, 48.2/100,000 inhabitants, but over 100,000 new cases per year (Hijjar 1992, Gerhardt Filho \& Hijjar 1993). PAHO considered it a worrying situation (Zacarias et al. 1994). The incidence stability observed during the last years may be related with the public medical assistance worsening, once the interaction between tuberculosis and HIV/Aids is still low (Hijjar 1992, Gerhardt Filho \& Hijjar 1993). Many studies, from 1987 to 1992 , observed an HIV infection prevalence of 5.6\% (0.5\% - 20.7\%) among patients with tuberculosis (Kritski et al. 1995). The increase of tuberculosis as the defining Aids illness, from $25.9 \%$ (1980-84) to $27.8 \%$ (1999), may be an indication of the infections overlap increase (Ministério da Saúde 1999). 
HIV infection is the most powerful known risk factor for tuberculosis development (Barnes \& Barrows 1993, Nunn et al. 1994). Among HIVinfected persons PPD reactivity $(\geq 5 \mathrm{~mm})$ is a well known risk factor (Selwyn et al. 1989, Barnes \& Barrows 1993, Ellner et al. 1993, Nunn et al. 1994, Toledo Jr et al. 1994), and the chemoprophylaxis in these cases has a protection effect (Whalen et al. 1997a, Halsey et al. 1998, Wilkinson et al. 1998). Highly active antiretroviral therapy (HAART) seems to have a protection effect also, as recent studies showed a low incidence of opportunistic infections, including tuberculosis, after HAART introduction (Borleffs et al. 1998, Viciana et al. 1998, Sparano et al. 1999). Contact with tuberculosis patients in prisons, shelters, hospitals, is also a risk factor (Stead 1978, Stead et al. 1985, Nardell et al. 1986). Recent exogenous infection or reinfection is a great risk factor, once $37 \%$ of HIV-infected patients recently infected developed tuberculosis in six months, against $2 \%$ to $5 \%$ of HIV-negative in two years (Nunn et al. 1994, Sepkowitz \& Raffalli 1994). A recent study showed exogenous reinfection as the main cause of recurrent tuberculosis after treatment (van Rie et al. 1999).

\section{MATERIALS AND METHODS}

Population - HIV-infected individuals, diagnosed from 1985 to 1996, were selected from the Immunodeficiency Sector of the Infectious and Parasitic Diseases Service (Universidade Federal de Minas Gerais and Belo Horizonte Health Department). This outpatient clinic is the main medical reference for HIV diagnosis and treatment in the State of Minas Gerais. All of them were HIVinfected (ELISA + Western Blot) and were evaluated from 1985 to 1996 . Other inclusion criteria were (1) 15 years of age or older, (2) for cases, tuberculosis diagnosis (positive sputum bacterioscopy or culture, or clinical and/or radiological evidence confirmed by treatment), and (3) for controls, not having tuberculosis after 15 years of age. The exclusion criteria were (1) not being HIV-infected; (2) for cases, having tuberculosis diagnosed more than one year before the HIV-infection diagnosis and (3) for controls, having had tuberculosis after 15 years of age.

The sample selected comprised 135 cases and 342 controls ( 2.5 controls:case). Case and controls were matched by year of birthday and by year of the first evaluation at the outpatient clinic and HIV risk factors (a maximum two years interval).

Variables - A special questionnaire, developed for this study, was used to collect demographic, social-economic, medical and laboratory data, at the moment of first evaluation, from the medical files. The following variables were analyzed: sex, marital status, race, personal monthly income, city of residence, presence of HIV related symptoms (Aids related complex - ARC - or CDC 1987 groups IV A and IV $C_{2}$ ) (CDC 1987), use of alcohol and tobacco, past history of pneumonia and hospitalization, lymphoadenomegaly, respiratory abnormalities, body mass index (BMI = weight in kilograms/height ${ }^{2}$ in meters), use of antiretroviral drugs, $\mathrm{PPD}$ (RT23-5U) reactivity (induration $\geq 5 \mathrm{~mm}$ ), anergy to skin tests (candida, tricophytin and streptokinase/streptodornase) and CD4+ lymphocytes count. The same nurse did all skin tests, including PPD, according to Mantoux technique. They were considered positive for an induration $\geq 5 \mathrm{~mm}$ (Stites 1991).

Statistical analysis - The analysis was performed with SPSS for Windows and the MULTLR (Campos-Filho \& Franco 1989) which allow a matched analysis with different number of controls per case. The variables with $p \leq 0.25$ in the univariate analysis were select for the stratified analysis. For logistic regression were select the variables which the adjusted odds ratio (OR) had a variation greater than $10 \%$ compared with the univariate OR. The variables with known biological importance were considered for the selection.

The logistic regression was done according to the stepwise method, considering the maximized log-likelihood (MLL) as the parameter (Hosmer \& Lemeshow 1989). In this method all variables selected in the stratified analysis were included in the initial model. Then, new models were elaborated by eliminating the variables, one-by-one, except for ARC. The sub-model maximized log-likelihood was compared with the MLL of the original one. The variables where the elimination resulted in minor impact in the MLL $(<10 \%)$ were excluded and the model was considered complete. The process was repeated until the identification of the final model, when the elimination of any variable caused a variation greater than $10 \%$ in the MLL.

\section{RESULTS}

Four hundred and seventy seven HIV-infected patients were selected for this study. The majority were men $(433-91 \%)$, single (349-73\%) and white (217-45.5\%). The age ranged from 16 to 61 years, with a mean of $33.2 \pm 7.7$ years. Tables I and II summarize demographic, social economic, medical and laboratory data.

Table III shows the results of the stratified analysis. The following variables were eliminated during the univariate analysis $(\mathrm{p}>0.25)$ : sex, marital status, race, alcohol use, PPD reactivity, anergy. 
TABLE I

Demographic and social-economic data from 477 human immunodeficiency virus-infected individuals - 1985-1996

\begin{tabular}{|c|c|c|c|c|c|c|}
\hline & & Case & Control & Total & OR (CI 95\%) & $\mathrm{p}$ \\
\hline \multirow[t]{2}{*}{ Sex } & Male & 121 & 312 & 433 & $1.2(0.5-2.7)$ & 0.6 \\
\hline & Female & 14 & 30 & 44 & & \\
\hline \multirow[t]{4}{*}{ Marital status } & Single & 100 & 249 & 349 & & \\
\hline & Married & 17 & 55 & 72 & $0.8(0.2-4.4)$ & 0.8 \\
\hline & Divorced & 11 & 27 & 38 & $0.9(0.4-1.9)$ & 0.8 \\
\hline & Others & 7 & 11 & 18 & $1.9(0.5-6.7)$ & 0.3 \\
\hline \multirow[t]{4}{*}{ Race } & White & 67 & 150 & 217 & & \\
\hline & Mulatto & 31 & 85 & 116 & $0.9(0.5-1.5)$ & 0.6 \\
\hline & Black & 5 & 10 & 15 & $1.0(0.3-3.8)$ & 1.0 \\
\hline & Unknown & 32 & 97 & 129 & & \\
\hline Monthly wage & (US\$) & $400 \pm 500$ & $330 \pm 380$ & $380 \pm 480$ & $1.04(1.01-1.06)$ & 0.001 \\
\hline \multirow{3}{*}{$\begin{array}{l}\text { City of } \\
\text { residence }\end{array}$} & Belo Horizonte & 105 & 245 & 350 & $0.7(0.4-1.1)$ & 0.09 \\
\hline & Others & 29 & 96 & 125 & & \\
\hline & Unknown & 1 & 1 & 2 & & \\
\hline
\end{tabular}

OR: odds ratio; $\mathrm{CI}$ : confidence interval; $\mathrm{p}$ : $\mathrm{p}$ value $\left(\mathrm{x}^{2}\right)$

During the logistic regression the body mass index was discarded due to its co-linearity with ARC. Table IV shows the statistical models from original to final ones.

Considering the five variables included in the logistic regression, there could be a bias between past history of hospitalization and ARC, if the tuberculosis diagnosis were made before the first evaluation in the HIV outpatient clinic. This is due to the fact that tuberculosis and ARC have similar symptoms and the possibility of the past hospitalization could be related to tuberculosis. In order to evaluate this bias, the original group was further divided in (1) patients with tuberculosis diagnosed during or after the first evaluation at the outpatient clinic, and (2) patients with tuberculosis diagnosed after this first evaluation. The ORs were recalculated for these new groups (Table V) and there were no differences among the new ORs for the five variables.

\section{DISCUSSION}

The high level of missing values that impaired the analysis of some variables and the impossibility of matching cases and controls by year of first evaluation in an interval less than six months may have introduced bias in the results.

The results show that the presence of ARC is an important clinical marker of tuberculosis, increasing in 3.5 times the chance of having the disease in the studied population. ARC is a clinical marker of immunodeficiency, which has a good correlation with high risk of opportunistic infections, included tuberculosis (Barnes \& Barrows 1993, Nunn et al. 1994, Ackah et al. 1995, Shafer et al. 1996).

The CD4 lymphocyte count does not have a good correlation with tuberculosis, once it could happen in patients with high CD4 count (> 350 cells/ $\left.\mathrm{mm}^{3}\right)$. This study shows a possible inverse protective effect, with high CD4 counts diminishing the chance of developing tuberculosis, but in this study it also has not reached statistical significance, probably due to a high number of missing values $(55.6 \%)$. In medical literature, the CD4 count cutoff for the risk of tuberculosis development is not clearly demonstrated. Despite this, there is a good inverse correlation between CD4 count and risk of developing opportunistic infections and death (Barnes \& Barrows 1993, Nunn et al. 1994, Ackah et al. 1995, Shafer et al. 1996).

Use of antiretroviral drugs has not reached statistical significance also, probably due to low access to these drugs and to the use of monotherapy, as current treatment, during the time of the study (before 1997). Recent studies showed a low incidence of opportunistic infections, including tuberculosis, after the introduction of HAART in 1997 (Borleffs et al. 1998, Viciana et al. 1998, Sparano et al. 1999).

An unexpected result was the lack of association between PPD reactivity and tuberculosis, which is well documented (Selwyn et al. 1989, Nunn et al. 1994). It may be related to the high level of missing values (164 patients, 34.4\%), once this association was observed in the same outpatient clinic by Toledo Jr. et al. in 1994. 
TABLE II

Medical and laboratorial data from 477 human immunodeficiency virus-infected individuals - 1985-1996

\begin{tabular}{|c|c|c|c|c|c|c|}
\hline & & Case & Control & Total & OR (CI 95\%) & $\mathrm{p}$ \\
\hline \multirow{2}{*}{$\begin{array}{l}\text { Aids related } \\
\text { complex }\end{array}$} & Yes & 105 & 165 & 270 & \multirow[t]{2}{*}{$3.7(2.3-6.0)$} & \multirow[t]{2}{*}{$<0.001$} \\
\hline & No & 30 & 177 & 207 & & \\
\hline \multirow[t]{3}{*}{ Alcohol use } & Yes & 47 & 111 & 158 & \multirow[t]{3}{*}{$0.9(0.6-1.5)$} & \multirow[t]{3}{*}{0.8} \\
\hline & No & 68 & 196 & 264 & & \\
\hline & Unknown & 20 & 35 & 55 & & \\
\hline \multirow[t]{4}{*}{ Tobacco use } & Never & 35 & 132 & 167 & \multirow[t]{4}{*}{$1.3(1.0-1.6)$} & \multirow[t]{4}{*}{0.05} \\
\hline & Stop smoking & 18 & 31 & 49 & & \\
\hline & Smoker & 66 & 154 & 220 & & \\
\hline & Unknown & 16 & 25 & 41 & & \\
\hline \multirow{3}{*}{$\begin{array}{l}\text { Past history of } \\
\text { pneumonia }\end{array}$} & Yes & 44 & 73 & 117 & \multirow[t]{3}{*}{$1.8(1.1-2.8)$} & \multirow[t]{3}{*}{0.01} \\
\hline & No & 81 & 250 & 331 & & \\
\hline & Unknown & 10 & 19 & 29 & & \\
\hline \multirow{3}{*}{$\begin{array}{l}\text { Past history of } \\
\text { hospitalization }\end{array}$} & Yes & 99 & 173 & 272 & \multirow[t]{3}{*}{$2.8(1.8-4.6)$} & \multirow[t]{3}{*}{$<0.001$} \\
\hline & No & 32 & 158 & 190 & & \\
\hline & Unknown & 4 & 11 & 15 & & \\
\hline \multirow[t]{3}{*}{ Lynphoadenomegaly } & Yes & 80 & 170 & 250 & \multirow[t]{3}{*}{$1.6(1.0-2.5)$} & \multirow[t]{3}{*}{0.04} \\
\hline & No & 48 & 161 & 209 & & \\
\hline & Unknown & 7 & 11 & 18 & & \\
\hline \multirow{3}{*}{$\begin{array}{l}\text { Respiratory } \\
\text { abnormalities }\end{array}$} & Yes & 24 & 36 & 60 & \multirow[t]{3}{*}{$1.9(1.0-3.4)$} & \multirow[t]{3}{*}{0.04} \\
\hline & No & 101 & 294 & 395 & & \\
\hline & Unknown & 10 & 12 & 22 & & \\
\hline \multirow[t]{3}{*}{ Body mass index } & $\geq 20$ & 37 & 122 & 159 & \multirow[t]{3}{*}{$1.0(1.0-1.0)$} & \multirow[t]{3}{*}{0.1} \\
\hline & $<20$ & 38 & 68 & 106 & & \\
\hline & Unknown & 60 & 152 & 212 & & \\
\hline \multirow[t]{2}{*}{ Antiretroviral use } & No & 66 & 217 & 283 & \multirow[t]{2}{*}{$1.9(1.2-2.9)$} & \multirow[t]{2}{*}{0.003} \\
\hline & Yes & 69 & 125 & 194 & & \\
\hline PPD reactivity & No reaction & 68 & 189 & 257 & $1.2(0.8-1.7)$ & 0.3 \\
\hline & Reactor & 4 & 10 & 14 & & \\
\hline & Strong reactor & 16 & 26 & 42 & & \\
\hline & Unknown & 47 & 117 & 164 & & \\
\hline Anergy $^{a}$ & Anergic & 65 & 152 & 217 & $1.1(0.6-1.8)$ & 0.8 \\
\hline & Reactor & 37 & 100 & 137 & & \\
\hline & Unknown & 33 & 90 & 123 & & \\
\hline CD4 count & $\leq 200$ cells & 30 & 84 & 114 & $0.7(0.4-1.4)$ & 0.3 \\
\hline & $201-500$ cells & 17 & 56 & 73 & & \\
\hline & $>500$ cells & 4 & 21 & 25 & & \\
\hline & Unknown & 84 & 181 & 265 & & \\
\hline
\end{tabular}

OR: odds ratio; $\mathrm{CI}$ : confidence interval; $\mathrm{p}$ : $\mathrm{p}$ value $\left(\mathrm{x}^{2}\right) ; a$ : antigens tested: candida, tricophytin, streptokinase/ streptodornase

The past history of pneumonia also seemed to increase the chance of tuberculosis, but it had no statistical significance. The significance reached by this variable in the univariate analysis is probably related to an information bias where the patients may refer to past tuberculosis as pneumonia. There is no data supporting an elevated tuberculosis risk due to a past pneumonia. It may also be a spurious association.
Past history of hospitalization does not reach statistical significance in logistic regression, but was selected in the univariate analysis. The possible risk of tuberculosis development associated to past hospitalization may be an indirect marker of exogenous infection or reinfection. Nosocomial transmission of $M$. tuberculosis is an important source of infection (Stead 1978, Stead et al. 1985, Nardell et al. 1986) and, as demonstrated by 
TABLE III

Stratified analysis from 477 human immunodeficiency virus-infected individuals - 1985-1996

\begin{tabular}{lccc}
\hline & Crude OR (CI 95\%) & Adjusted OR (CI 95\%) & $\mathrm{p}$ \\
\hline Monthly wage & $1.04(1.01-1.06)$ & $1.03(1.01-1.06)$ & 0.004 \\
City of residence & $0.7(0.4-1.1)$ & $0.6(0.4-1.0)$ & 0.08 \\
Tobacco use & $1.3(1.0-1.6)$ & $1.3(1.0-1.6)$ & 0.07 \\
Past history of pneumonia & $1.8(1.1-2.8)$ & $1.5(0.9-2.4)$ & 0.12 \\
Past history of hospitalization & $2.8(1.8-4.6)$ & $2.2(1.3-3.6)$ & 0.003 \\
Body mass index & $1.0(1.0-1.0)$ & $1.0(1.0-1.0)$ & 0.07 \\
Lymphoadenomegaly & $1.6(1.0-2.5)$ & $1.6(1.0-2.5)$ & 0.06 \\
Respiratory abnormalities & $1.9(1.0-3.4)$ & $1.2(0.7-2.3)$ & 0.5 \\
CD4 lymphocytes count & $0.7(0.4-1.4)$ & $0.8(0.4-1.8)$ & 0.6 \\
No antiretroviral use & $1.9(1.2-2.9)$ & $2.1(1.4-3.4)$ & 0.001
\end{tabular}

OR: odds ratio; $\mathrm{CI}$ : confidence interval; $\mathrm{p}$ : $\mathrm{p}$ value $\left(\mathrm{x}^{2}\right)$

TABLE IV

Logistic regression analysis from 477 human immunodeficiency virus-infected individuals (OR-CI 95\%) $-1985-1996$

\begin{tabular}{lcccccc}
\hline Model & ARC & Pneumonia & Hospitalization & CD4 & No antiretroviral & $\mathrm{MML}^{a}$ \\
\hline 1 & 3 & 1.6 & 1.5 & 0.5 & 1.1 & 49.795 \\
& $(0.9-9.8)$ & $(0.5-5.5)$ & $(0.5-4.9)$ & $(0.2-1.4)$ & $(0.3-3.9)$ & \\
2 & 3 & 1.5 & 1.5 & 0.4 & & 49.8378 \\
& $(0.9-9.8)$ & $(0.5-4.8)$ & $(0.5-4.9)$ & $(0.2-1.2)$ & & 50.4431 \\
Final & 3.5 & 1.7 & & 0.4 & & \\
& $(1.2-10.8)$ & $(0.6-5.2)$ & & $(0.2-1.2)$ & & \\
\hline
\end{tabular}

OR: odds ratio; CI: confidence interval; ARC: Aids related complex; $a$ : maximized log-likelihood

TABLE V

Bias analysis from 477 human immunodeficiency virus-infected individuals (OR-CI 95\%) - 1985-1996

\begin{tabular}{ccccccc}
\hline Group & No. & ARC & Pneumonia & Hospitalization & CD4 & No antiretroviral \\
\hline Original & 477 & 3.7 & 1.8 & 2.8 & 0.9 & 1.9 \\
& & $(2.3-6.0)$ & $(1.1-2.8)$ & $(1.8-4.6)$ & $(0.7-1.1)$ & $(1.2-2.9)$ \\
$(1)$ & 421 & 3.7 & 1.8 & 2.7 & 0.7 & 2.1 \\
& & $(2.2-6.2)$ & $(1.1-3.0)$ & $(1.6-4.6)$ & $(0.4-1.5)$ & $(1.3-3.3)$ \\
$(2)$ & 361 & 4.1 & 2.1 & 2.8 & 0.7 & 2.0 \\
& & $(2.2-7.4)$ & $(1.2-3.6)$ & $(1.6-5.1)$ & $(0.3-1.5)$ & $(1.2-3.3)$ \\
\hline
\end{tabular}

OR: odds ratio; CI: confidence interval; ARC: Aids related complex; (1) patients with tuberculosis diagnosed during or after the first evaluation at the outpatient clinic; (2) patients with tuberculosis diagnosed after this first evaluation.

Sepkowitz (1994) and Nunn (1994), recent exogenous infection or reinfection is a great risk factor for tuberculosis development among HIV-infected patients. Van Rie (1999) demonstrated that exogenous reinfection may be the main cause of recurrent tuberculosis after treatment.

Tuberculosis has a high impact on HIV-infected patients and this interaction may accelerate the progression of both diseases. The prognosis is often poor, albeit it depends on the immunosupression degree and to the response to antitu- berculosis drugs (Ackah et al. 1995, Shafer et al. 1996, Whalen et al. 1997b). Recent studies confirmed the chemoprophylaxis value for tuberculosis protection among HIV-infected patients with PPD positive reaction (Whalen et al. 1997a, Halsey et al. 1998, Wilkinson et al. 1998) and this could be the most important strategy for tuberculosis control in this population. Other strategies, as early diagnosis and treatment, and BCG vaccination are limited in HIV infection, because of atypical clinical presentations, diagnosis delay and lack of safety 
data about BCG vaccination in this population.

The PPD reactivity is the currently used marker in clinical practice, but it has limited value due to high anergy prevalence in HIV/Aids patients, which increases with disease progression. The definition of better surrogate markers is still necessary. According to the results here reported, the presence of Aids related symptoms (ARC) increases the risk for tuberculosis 3.5 times, suggesting that the ideal moment for chemoprophylaxis may be much earlier than what is currently considered, either before the need of antiretroviral treatment or immediately after the diagnosis of HIV infection.

\section{REFERENCES}

Ackah A, Coulibaly D, Digbeu H, Diallo K, Vetter K, Coulibaly I, Greenberg A, De Cock K 1995. Response to treatment, mortality, and CD4 lymphocyte counts in HIV-infected persons with tuberculosis in Abidjan, Côte d'Ivoire. Lancet 345: 607-610.

Arachi A 1991. The global tuberculosis situation and the new control strategy of the World Health Organization. Tubercle 72: 1-6.

Barnes PF, Barrows SA 1993. Tuberculosis in the 1990s. Ann Intern Med 119: 400-410.

Borleffs JC, Schneider MM, Hoepelman IM 1998. A changed pattern of opportunistic infections and malignancies in HIV- seropositive patients after the introduction of intensive anti-HIV-combination therapy. Ned Tijdschr Geneeskd 142: 2395-9.

Campos-Filho N, Franco EL 1989. A microcomputer program for multiple logistic regression by uncoditional and conditional maximum likelihood methods. Amer J Epidemiol 129: 439-444.

Cantwell MF, Snider DEJ, Cauthen GM, Onorato IM 1994. Epidemiology of tuberculosis in the United States, 1985 through 1992. JAMA 272: 535-539.

CDC - Centers for Disease Control and Prevention 1987. Revision of the CDC surveillance case definition for acquired immunodeficiency syndrome. $M M W R$ 36: $1 \mathrm{~S}-15 \mathrm{~S}$.

Citron KM 1988. Control and prevention of tuberculosis in Britain. Br Med Bull 44: 704-716.

Ellner J, Hinman A, Dooley S, Fischl M, Sepkowitz K, Goldberger M, Schinnick T, Iseman M, Jacobs WJ 1993. Tuberculosis symposium: emerging problems and promise. J Infect Dis 168: 537-551.

Gerhardt Filho G, Hijjar MA 1993. Aspectos epidemiológicos da tuberculose no Brasil. J Pneumol 10: 4-10.

Halsey N, Coberly J, Desormeaux J, Losikoff P, Atkinson J, Moulton L, Contave M, Johnson M, Davis H, Geiter L, Johnson E, Huebner R, Boulos R, Chaisson $R$ 1998. Randomised trial of isoniazid versus rifampicin and pyrazinamide for prevention of tuberculosis in HIV-1 infection. Lancet 351: 786792.

Hijjar MA 1992. Epidemiologia da tuberculose no Brasil. Informe Epidemiológico do SUS Novembro: 53-87.
Hosmer DW, Lemeshow S 1989. Applied Logistic Regression, Wiley Interscience, New York, 307 pp.

Kantor IN, Astarloa L, Gonzalez Montaner LJ 1994. Asociación entre tuberculosis e infección por virus de la inmunodeficiencia humana en la Argentina. Bol Oficina Sanit Panam 116: 356-366.

Kritski A, Dalcolmo M, Del Bianco R, Melo FM, Pinto W, Schechther M, Castelo E 1995. Associação tuberculose e infecção pelo HIV no Brasil. Bol Oficina Sanit Panam 118: 542-554.

Ministério da Saúde 1999. AIDS, Boletim Epidemiológico 12.

Nardell E, McInn B, Thomas B, Weidhass S 1986. Exogenous reinfection with tuberculosis in a shelter for the homeless. N Eng J Med 315: 1570-5.

Nunn P, Elliott AM, McAdam KP 1994. Impact of human immunodeficiency virus on tuberculosis on developing countries. Thorax 49: 511-518.

Rieder HL, Cauthen GM, Kelly GD, Bloch AB, Snider DEJ 1989. Tuberculosis in the United States. JAMA 262: 385-389.

Selwyn PA, Hartel D, Lewis VA, Schoenbaun EE, Vermund SH, Klein RS, Walker AT, Friedland GH 1989. A prospective study of the risk of tuberculosis among intravenous drug users with human immunodeficiency virus infection. N Eng J Med 320: 545-550.

Sepkowitz KA, Raffalli J 1994. Tuberculosis at the end of the twentieth century. Eur J Clin Microbiol Infect Dis 13: 902-907.

Shafer B, Bloch A, Larkin C, Vasudavan V, Seligman S, Dehovitz J, DiFerdinando G, Stoneburner R, Cauthen $\mathrm{G}$ 1996. Predictors of survival in HIV-infected tuberculosis patients. AIDS 10: 269-272.

Sparano JA, Anand K, Desai J, Mitnick RJ, Kalkut GE, Hanau LH 1999. Effect of highly active antiretroviral therapy on the incidence of HIV-associated malignancies at an urban medical center. $J$ Acquir Immune Defic Syndr 21 (Suppl. 1): S18-22.

Stead WW 1978. Undetected tuberculosis in prison. Source of infection of community at large. JAMA 240: 2544-2547.

Stead WW, Lofgren JP, Warren E, Thomas C 1985. Tuberculosis as an endemic and nosocomial infection among the elderly in nursing homes. $N$ Eng $\mathrm{J} \mathrm{Med}$ 312: 1483-1487.

Stites D 1991. Clinical laboritory methods for detection of cellular immunity. In D Stites, A Terr (eds), Basic and Clinical Immunology, East Norwalk, Appleton \& Lange, p. 263-283.

Styblo K 1989. Overview and epidemiologic assessment of the current global tuberculosis situation with an emphasis on control in developing countries. Rev Infect Dis 11: S339-S346.

Toledo Jr. AC, Vitoria MAA, Castro AL, Padua CAJ, Nunes CM, Greco DB 1994. PPD as a predictor of tuberculosis in HIV $(+)$ persons in Brazil. X International Conference on AIDS, Tokio.

van Rie A, Warren R, Richardson M, Victor T, Gie R, Enarson D, Beyers N, van Helden P 1999. Exogenous reinfection as a cause of recurrent tuberculosis after 
curative treatment. N Eng J Med 341: 1174-1179.

Viciana P, Miralles-Martin P, Knobel H, Gatell JM 1998. Prevention of opportunistic infections in the protease inhibitor era. Enferm Infecc Microbiol Clin 16: 1-10.

Whalen C, Johnson J, Okwera A, Hom D, Huebner R, Mugyenyi P, Mugerwa R, Ellner J, for the UgandaCase Western Reserve University Research Collaboration 1997a. A trial of three regimens to prevent tuberculosis in Ugandan adults infected with the human immunodeficiency virus. $N$ Eng $J$ Med 337: 801-808.
Whalen C, Horsburgh CJ, Hom D, Lahart C, Simberkoff M, Ellner J 1997b. Site of disease and opportunistic infection predict survival in HIV-associated tuberculosis. AIDS 11: 455-460.

Wilkinson D, Squire S, Garner P 1998. Effect of preventive treatment for tuberculosis in adults infected with HIV: systemic review of randomised placebo controlled trials. BMJ 317: 625-629.

Zacarias F, Gonzalez RS, Cuchi P, Yanez A, Peruga A, Mazin R, Betts C, Weissenbacher M 1994. El SIDA y su interación con la tuberculosis en América Latina y el Caribe. Bol Oficina Sanit Panam 116: 250-263. 